\title{
Response of fishes to algae reduction on Glovers Reef, Belize
}

\author{
T. R. McClanahan ${ }^{1, *}$, K. Bergman ${ }^{2}$, M. Huitric ${ }^{3,4}$, M. McField ${ }^{5}$, \\ T. Elfwing ${ }^{3}$, M. Nyström ${ }^{3}$, I. Nordemar ${ }^{3}$ \\ ${ }^{1}$ The Wildlife Conservation Society, PO Box 99470, Mombasa, Kenya \\ ${ }^{2}$ Department of Zoology, University of Stockholm, Stockholm, Sweden \\ ${ }^{3}$ Department of Systems Ecology, University of Stockholm, Stockholm, Sweden \\ ${ }^{4}$ Beijer International Institute for Ecological Economics, Royal Swedish Academy of Sciences, Sweden \\ ${ }^{5}$ Department of Marine Sciences, University of South Florida, St. Petersburg, Florida, USA
}

\begin{abstract}
Many Caribbean coral reefs have experienced an increase in erect brown algae (species of Sargassum, Turbinaria and Lobophora) over the past $18 \mathrm{yr}$. We explored the effects of fleshy algal overgrowth on coral reef fishes by reducing erect algae by $\sim 2.5 \mathrm{~kg}$ (wet) $\mathrm{m}^{-2}$ on 8 patch reefs (average size $\sim 1000 \mathrm{~m}^{2}$ ) whereby half were in a new no-fishing zone and half in an unrestricted fishing zone. Another 8 reefs were left as unmanipulated controls in the respective zones. Multivariate ordination indicated that the algal removal had marginal effect on whole-fish assemblages but that effect was highly significant on the biomass of common herbivores. The reduction of erect algae resulted in a rapid increase in the abundance of the blue-headed wrasse Thalassoma bifasciatum (Labridae), in the biomass of the blue tang Acanthurus coeruleus (Acanthuridae), and in both the abundance and biomass of the spotlight parrotfish Sparisoma viride (Scaridae). Bite rates and intra- and inter-specific aggressive encounters were used as measures of resource quality, and we found that these measures increased for surgeonfishes and damselfishes after the algal reduction, particularly in the center of the patch reefs, where most erect algae was originally located. Increased accessibility, net production and palatability of the early successional turf algae on the manipulated reefs are likely to account for the increased numbers, biomass and feeding rates of the dominant herbivorous fishes.
\end{abstract}

KEY WORDS: Acanthuridae $\cdot$ Algal-fish interactions $\cdot$ Brown algae $\cdot$ Herbivory $\cdot$ Labridae $\cdot$ Management interactions $\cdot$ Sargassum $\cdot$ Scaridae $\cdot$ Turbinaria

Resale or republication not permitted without written consent of the publisher

\section{INTRODUCTION}

Coral reefs in the Caribbean have experienced a large-scale change in their ecology over the past 2 decades resulting in the loss of hard coral cover and reefs dominated by various forms of fleshy algae (Carpenter 1990, Hughes 1994, Connell 1997, Shulman \& Robertson 1997, McClanahan \& Muthiga 1998, McClanahan et al. 1999a). This ecological change has been associated with the disease-induced die-offs of corals

*E-mail: crcp@africaonline.co.ke
(Aronson et al. 1998) and of an important grazing sea urchin (Diadema antillarum) (Lessios 1988, Hughes et al. 1999), coral bleaching (Porter \& Meier 1992, Glynn 1993, Shulman \& Robertson 1997, Winter et al. 1998), cyclones (Woodley et al. 1981, Done 1992, Rogers 1993, Mumby 1999), and increased fishing pressure (Koslow et al. 1988, Hughes 1994) and seawater nutrient concentrations (Cockey et al. 1996, LaPointe 1999). The consequences of this large-scale macroalgal overgrowth for coral reef fishes have been poorly explored, apart from a study in the Watamu Marine National Park, a 25 yr-old unfished park in a Kenyan reef lagoon, which found that increased abundances of her- 
bivorous and invertebrate-eating fishes followed the experimental reduction of fleshy algae (McClanahan et al. 1999b). The considerable age of the Watamu Park assured sufficient time for the recovery of fishes from fishing disturbances, and the response may differ in areas more recently closed to fishing. The recovery of herbivore populations could help restore reefs dominated by fleshy algae to coral domination. Therefore, studies of the interaction between fishing, reduction of macroalgae, and time since initiation of management should be useful in planning restoration of reefs dominated by macroalgae.

Ecological interactions combined with fishing may produce complex responses to ecological changes or perturbations (Knowlton 1992, McClanahan 1995, 1999, McClanahan et al. 1995). For example, increases in late successional macroalgae may increase the structural refuge for small invertebrates (Duffy \& Hay 1991, Wahl \& Hay 1995, Stachowicz \& Hay 1996), which could enhance resources for invertebrate-feeding fishes if fishing is not strongly influencing their populations. Late successional algae may, however, have lower photosynthetic rates and net production, as well as a reduced nutritive content and increased chemical defences, resulting in lower palatability than early successional opportunistic turf algae (Littler \& Littler 1980, Birkeland et al. 1985, Steneck \& Dethier 1994). Late successional algae could, therefore, reduce the benthic production available to consumers directly (to herbivorous) and indirectly (to invertebrate-consumers) (McClanahan et al. 1999b). The immediate response of fishes to a reduction in late successional algae is likely to be manifested first in herbivorous fishes, as these are most likely to respond to an increase in their preferred turf algal food (Choat 1991, van Rooij et al. 1996a, Lawson et al. 1999). The response may, however, depend on the species' feeding behavior and the morphology of the feeding apparatus (Bellwood 1990, Bruggemann et al. 1994b, Polunin et al. 1995). Therefore, the successional state of algae is likely to influence the distribution and abundance of herbivorous species according to their feeding behavior (e.g. browsing, scraping, excavating) (McClanahan et al. 1999b).

This study reports the results of an experiment whereby macroalgae were reduced on patch reefs in the lagoon of the remote Glovers Reef atoll (Belize, Central America). These patch reefs have experienced a large increase in macroalgae over the past $\sim 20 \mathrm{yr}$, particularly by late successional brown algae (McClanahan \& Muthiga 1998). The southern end of this atoll was closed to fishing in 1996. Our study focused on the immediate response of fishes to the algal reduction with particular focus on the response of herbivorous surgeon (Acanthuridae), damsel (Pomacentridae) and parrotfishes (Scaridae). Our working hypotheses were that macroalgae inhibit the feeding rates of herbivorous fishes, while invertebrate-feeders, such as wrasses (Labridae), grunts (Haemulidae) and snappers (Lutjanidae), would have variable or delayed responses (McClanahan et al. 1999b). The greater net production and palatability of early successional turfs (Choat 1991, Steneck \& Dethier 1994) was hypothesized to increase accessible algal resources, which in turn should lead to greater feeding rates and aggression between ecologically similar individuals (Carpenter \& MacMillen 1976, Eakin 1987, van Rooij et al. 1996a). This study was undertaken to determine if the generally positive response of fishes to the reduction of algae in the Kenyan study is also applicable to the Caribbean, where the largest recent increases in fleshy brown algae have been reported (Connell 1997).

\section{METHODS}

Study sites and management. Glovers Reef is a $260 \mathrm{~km}^{2}$ atoll located approximately $15 \mathrm{~km}$ east of the Belizean Barrier reef - the largest reef in the Atlantic (see Stoddart 1962, Wallace \& Schafersmann 1977, Gischler 1994 for further geologic descriptions). The atoll is an almost continuous reef, with 3 large tidal channels and $\sim 850$ patch reefs within the lagoon. The outer edge of the atoll drops into deep water $(>500 \mathrm{~m})$, while the central lagoon seldom exceeds $20 \mathrm{~m}$ in depth. Patch reefs, the focus of the study, occur in the lagoon and vary in size from $\sim 25$ to $\sim 10000 \mathrm{~m}^{2}$. The patch reefs are separated by sand and seagrass beds at a depth of 4 to $20 \mathrm{~m}$, with the distance between the nearest-neighbor patch reef seldom exceeding $30 \mathrm{~m}$. Patch reefs consist of massive coral species (the genera Montastrea, Diploria, Siderastrea, Porites) with occasional thickets of Agaricia agaricites and A. cervicornis. Sea fans (Gorgonia ventalina), sea whips (genera Eunicea, Plexaurella, Pseudoplexaura) and brown algae (genera Lobophora, Dictyota, Turbinaria, Sargassum) are abundant on most patch reefs (McClanahan \& Muthiga 1998).

Despite the remoteness of the atoll, fishing is practiced by a small number of residents and a larger number of transient fishers. Fishers collect lobsters, conches and finfishes using spear, hook and line. The Belizean Fisheries Department zoned the atoll into 4 fisheries management zones and began management in June 1996. The southern half of the atoll is divided into 3 zones: 'wilderness', 'conservation' and 'general use' zones. The wilderness and conservation zones exclude all forms of fishing except by a small number $(<10)$ of residents who can fish only for personal consumption in the conservation zone. The general use zone allows the controlled continuation of existing 
fisheries practices. The fourth zone is a seasonal closure area of a grouper spawning ground on the northeast end of the atoll.

Experimental design and algal reduction logistics. We haphazardly selected 16 patch reefs of moderate size $\left(985 \pm 173 \mathrm{~m}^{2}\right)$ such that 8 were located in the wilderness and general use zones respectively. We used a balanced design, whereby 4 patch reefs in each of the 2 management zones were selected for the macroalgae reduction (experimental patch reefs) and 4 were left unmanipulated as controls (a small portion of the largest experimental patch reefs was not cleared on the leeward side). Water depth to the bottom of the patch reefs did not exceed $4 \mathrm{~m}$, and the distance between reefs used for the algal reduction was $>15 \mathrm{~m}$ (although some control reefs were $<10 \mathrm{~m}$ from experimental reefs). All patch reefs were studied approximately $1 \mathrm{wk}$ prior to and $1 \mathrm{wk}$ after algae reduction in September and October 1998, respectively. Algae was removed in 2 steps. First, the large fronds were cleared with hedge-trimmers, and the remaining holdfasts were then cleared using wire brushes. An average of 28 person-hours was allotted to the clearing of each patch reef. Algae were scraped from 3 replicate $0.0625 \mathrm{~m}^{2}$ plots on each patch reef before and after the clearance to estimate the change in the wet weight of macroalgae. From these measurements we roughly estimated a wet weight algal reduction of $\sim 2.5 \mathrm{~kg} \mathrm{~m}^{-2}$ or $\sim 1250 \mathrm{~kg}^{-1}$ patch reef.

Benthic cover estimates. Benthic cover was estimated on each patch reef using the line-intercept method (McClanahan \& Shafir 1990). A 10 m transect line was haphazardly laid in 3 locations on the growing front (NE compass direction) of the patch reef. The 3 locations were the patch reef edge (transition from sand to patch reef), shoulder and center. Substrate cover was separated into functional groups: hard corals, fleshy algae, algal turf, calcareous algae, encrusting coralline algae, branching coralline algae, gorgonians, sponges, zoanthids, seagrasses, sand and 'microalgae', the latter including diatoms and cyanobacteria. All groups covering a distance of $3 \mathrm{~cm}$ or more were measured to the nearest $1 \mathrm{~cm}$, recorded on a plastic slate, and used for calculating percentage cover for each functional group. It should be noted that this method only measures groups composing the canopy, and the results therefore represent relative canopy-cover abundances. Sand and seagrass areas were avoided when laying out the transect lines, and therefore their estimated abundances do not necessarily represent their true cover on these patch reefs.

Fish counts. Visual counts were carried out using the discrete groups sampling (DGS) method (Greene \& Alevizon 1989, McClanahan 1994), whereby a limited number of species are sampled during a single search-sampling period of $5 \mathrm{~min}$. During the total 35 min sampling period, the investigator swam haphazardly over each patch reef, and recorded the number of species and individuals of 7 groups, each allotted a 5 min observation interval. Individuals of $<3 \mathrm{~cm}$ were not counted. Each of the following 7 discrete groups were sampled separately: Group 1: Chaetodontidae (butterflyfishes) and Pomacanthidae (angelfishes); Group 2: Acanthuridae (surgeonfishes); Group 3; Haemulidae (grunts); Lutjanidae (snappers) and Sparidae (porgies); Group 4: Scaridae (parrotfishes); Group 5: Labridae (wrasses); Group 6: Sphyraenidae (barracuda), Balistidae (triggerfishes), Carangidae (jacks), Aulostomidae (trumpetfishes) and Fistulariidae (cornetfishes), and Chromis cyanea; Group 7: Serranidae (groupers, of which graysby comprised $>95 \%$ of the observations) and territorial pomacentrids (damselfishes). All surgeonfishes and parrotfishes were assigned to 8 different $5 \mathrm{~cm}$ size-class intervals. Size-frequency data was converted to biomass, using length-weight relationships from an NOAA technical paper (Bohnsack \& Harper 1998).

Herbivore bite and aggression rates. In order to estimate the potential effects of algal reduction on feeding of herbivorous fishes, direct observations of feeding were carried out on patch reefs where the algae had been cleared as well as on control reefs. Observations on bite rates and aggression were carried out on the 2 most common species of surgeonfish Acanthurus coeruleus (blue tang) and A. bahianus (ocean surgeonfish), 2 species of territorial damselfishes (Stegastes fuscus and S. planifrons), and on the dominant parrotfish, Sparisoma viride (spotlight parrotfish). Fish foraging behavior on the edge and shoulder of the patch reef was compared to that of the center of the reef. The observer followed each haphazardly selected individual for a $1 \mathrm{~min}$ observation period, during which all bites on substrate were recorded as well as all interactions or attack rates on other fishes (McClanahan et al. 1999b).

Data analyses. The percentage cover of each functional group was calculated for each patch reef based on the pooled transect data. We only present benthic cover data for the experimental patch reefs, as no significant differences were found between control and experimental patch reefs prior to the treatment (Student's $t$-tests, $\mathrm{p}>0.05)$. Two-way ANOVAs were used to determine the effects of time, management and their interaction on the relative cover of the functional groups.

In order to confirm uniformity in fish assemblages among patch reefs in each respective management zone prior to algal removal, independent $t$-tests were conducted. To investigate the effects of algal removal on the structure of fish assemblages, data were sub- 
jected to non-metric multidimensional scaling (MDS) using the Bray-Curtis similarity measure (Clarke 1993). The average of 2 repeated surveys on each reef was used in all fish analyses. Prior to the multivariate analyses, both fish numbers and biomass of selected species were double square-root-transformed to enhance the contribution of less abundant species. Differences in fish assemblages between the 2 management zones, as well as between treatments, were examined using a 2-way crossed ANOSIM, which is an analogue of multivariate analysis of variance with a randomization test for significance (Clarke 1988). Where the ANOSIM revealed significant differences among groups of samples, similarity percentage analysis (SIMPER) was used to identify the percentage contribution of individual species (i), to the average amonggroup dissimilarity $\bar{\delta}$ (Warwick et al. 1990). The BrayCurtis measure of dissimilarity $\bar{\delta}$ (Bray \& Curtis 1957) takes on values in the range 0 to 100 , with $\bar{\delta}=100$ representing the case of no species in common and $\bar{\delta}=0$ being 2 samples with identical species patterns. When the mean species-specific contribution to $\bar{\delta}\left(\bar{\delta}_{i}\right)$ is large and the standard deviation $\left(\bar{\delta}_{i} / \mathrm{SD}\left[\delta_{i}\right]\right)$ is low, the $i$ th species constitutes a good discriminating species because of its consistent contribution to the dissimilarity (Clarke 1993). Finally, the effect of the algae reduction on individual species abundance and biomass was examined with a 2-way fixed factor ANOVA.

Where necessary, benthic data was arcsine-transformed and fish data was $\log _{10}(x+1)$ or square-roottransformed to meet the assumption of homogeneity of variances (Cochran's $C, \mathrm{p}>0.05$ ). Repeated testing (e.g. ANOVA and $t$-tests) can lead to decision errors, particularly at the $\mathrm{p}<0.05$ to 0.01 levels. In this study both benthic and fish data consisted of numerous variables, and therefore the sequential Bonferroni technique, which adjusts the $\alpha$-value according to the number of variables included, was applied (Holm 1979). In order to relate the adjusted $\alpha$-values to their unadjusted counterparts we use the symbols ${ }^{*} \mathrm{p}<0.05$, ${ }^{* *} \mathrm{p}<0.01$ and ${ }^{* * *} \mathrm{p}<0.001$. Bite and aggression rates of herbivorous fish were analyzed with the KruskalWallis non-parametric test.

\section{RESULTS}

\section{Benthic cover}

Algae reduction targeted macroalgae, which led to an expected decrease in fleshy algae (ANOVA, p < $\left.0.00008^{* * *}\right)$, and a significant decrease in both calcareous and branching coralline algae (ANOVA, p < $0.006 *$; Table 1 ). As a result of the reduction in the macroalgae, turf algae became more visible and therefore appeared more abundant in the canopy (ANOVA, $\left.\mathrm{p}<0.00009^{* * *}\right)$. This was however an artifact resulting from the opened canopy following macroalgae reduction. Management did not affect benthic cover (ANOVA, p > 0.05) exept that coral cover was higher in the general use zone $(p<0.05)$. However, the interaction of management and algae reduction was significant for fleshy algae (ANOVA, p $<0.004^{*}$ ). This may have been due to the fact that algae cover prior to the removal was higher in the wilderness zone and hence the removal in this zone had a stronger effect (Table 1).

\section{Fish response}

Prior to the algal reduction, fish assemblages on the patch reefs were similar within each management zone (ANOSIM, p > 0.05), as was the abundance and biomass of individual species $\left(t\right.$-tests, $\left.p>0.008^{*}\right)$. The

Table 1. Mean \% ( \pm SE) cover of the functional groups in the 2 management areas: wilderness zone and general use zone

\begin{tabular}{|c|c|c|c|c|}
\hline \multirow{2}{*}{ Functional groups } & \multicolumn{2}{|c|}{ __ Wilderness zone } & \multicolumn{2}{|c|}{ General use zone } \\
\hline & Pre-removal & Post-removal & Pre-removal & Post-removal \\
\hline Hard coral & $20.2(2.1)$ & $26.0(2.8)$ & $28.7(2.8)$ & $34.4(2.3)$ \\
\hline Turf & $12.4(3.0)$ & $43.4(3.6)$ & $18.9(1.7)$ & $36.1(2.4)$ \\
\hline Calcareous algae & $7.8(2.3)$ & $3.2(0.8)$ & $5.4(0.5)$ & $1.9(0.4)$ \\
\hline Fleshy algae & $37.7(2.1)$ & $4.4(0.8)$ & $25.0(2.6)$ & $8.5(0.8)$ \\
\hline Encrusting coralline algae & $3.2(1.1)$ & $8.6(3.7)$ & $2.9(0.6)$ & $4.0(0.6)$ \\
\hline Branching coralline algae & $2.8(0.8)$ & $0.8(0.3)$ & $3.8(1.1)$ & $1.2(0.5)$ \\
\hline Seagrass & $1.0(0.6)$ & $0.1(0.1)$ & $0.2(0.2)$ & $0.0(0.0)$ \\
\hline Sand & $1.6(0.3)$ & $1.8(0.5)$ & $2.5(0.3)$ & $0.8(0.5)$ \\
\hline Gorgonia & $7.1(2.2)$ & $5.6(2.0)$ & $7.5(2.3)$ & $8.7(3.1)$ \\
\hline Sponge & $4.8(1.8)$ & $5.8(2.0)$ & $3.3(0.7)$ & $4.4(0.7)$ \\
\hline Zoanthid & $0.1(0.1)$ & $0.1(0.1)$ & $0.6(0.1)$ & $0.1(0.1)$ \\
\hline Microalgae & $1.3(0.7)$ & $0.1(0.1)$ & $1.5(0.6)$ & $0.0(0.0)$ \\
\hline Patch reefs (n) & 4 & 4 & 4 & 4 \\
\hline
\end{tabular}


reduction of algae influenced whole-fish assemblages and caused significant change in the biomass of common herbivores. Multivariate scaling ordination (MDS) illustrated certain dissimilarity in whole-fish assemblages between control and experimental reefs (ANOSIM, $\mathrm{p}=0.056$; SIMPER, $\bar{\delta}=24.26$; Fig. 1). The responses of individual species and families are presented in Table 2. Species and family-wise analyses of variance revealed a highly significant effect of the algae removal on Sparisoma viride $\left(\mathrm{p}<0.0005^{* *}\right)$ and a significant effect on Thalassoma bifasciatum ( $p<$ $\left.0.003^{*}\right)$. The effect of the algae removal on herbivore biomass could be determined by subjecting the biomass of common surgeon- and parrotfishes to MDS (Fig. 2). The difference in biomass of parrot- and surgeonfishes between control and experimental patch reefs was highly significant (ANOSIM, p < 0.01). The Bray-Curtis average dissimilarity $(\bar{\delta})$ between control and experimental reefs was 19.57, a relatively low value, attributable to the fact that the ordination was carried out on a small part of the fish assemblages, i.e. on the biomass of common herbivores. The almost 6 times higher biomass of $S$. viride on experimental reefs explained almost $30 \%$ of the Bray-Curtis dissimilarity, and its contribution to the overall dissimilarity between control and experimental reefs was also the most consistent (SIMPER, $\bar{\delta}_{i} / \mathrm{SD}\left[\delta_{i}\right]=2.49$; Table 3 ). Univariate analyses of species-specific effects of algae removal on biomass support the conclusions from the SIMPER procedure, as they were significant for 2 individual species, $S$. viride and Acanthurus coeruleus

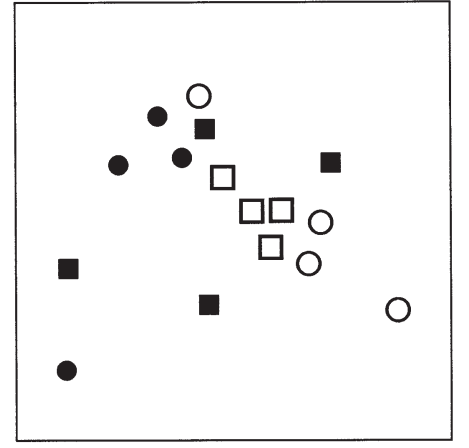

Fig. 1. Multidimensional scaling plots based on population densities of 46 fish species on patch reefs in Glovers Reef lagoon. Of the fish assemblages observed, 8 were sampled on patch reefs in the wilderness zone, and 8 were sampled in the general use zone. The fish fauna was examined after macroalgae had been removed from half of the reefs in each zone. A stress value of 0.13 indicated that the 2-dimensional ordination constituted a good representation of a relationship in multidimensional space. (O) wilderness zone control, (๑) wilderness zone experiment, $(\square)$ general use zone control, (ם) general use zone experiment

(ANOVA, $\mathrm{p}<0.008^{*}$ and $\mathrm{p}<0.01^{*}$ respectively). The biomass of $A$. coeruleus on experimental reefs was 2fold that on control reefs. For 2 species, A. chirurgus and Scarus croicensis, biomass decreased on reefs from which algae had been removed (Table 3).

In contrast, management had no effect on whole-fish assemblages (ANOSIM, p = 0.57). Only adult Acanthu-

Table 2. Mean $( \pm \mathrm{SE})$ fish abundance per 5 min count in the 2 management zones and in the 2 treatments. Total of 46 species of fish were recorded on the 16 examined patch reefs in Glovers Reef lagoon. Many of the species were uncommon and/or displayed erratic distribution and were therefore pooled into families in order to facilitate interpretation of results

\begin{tabular}{|c|c|c|c|c|}
\hline \multirow[t]{2}{*}{ Family/species } & \multicolumn{2}{|c|}{ Wilderness zone } & \multicolumn{2}{|c|}{ General use zone } \\
\hline & Control & Removal & Control & Removal \\
\hline Serranidae & $1.8(0.7)$ & $0.5(0.4)$ & $0.3(0.3)$ & $1.0(0.3)$ \\
\hline Haemulidae & $65.8(22.0)$ & $69.8(4.6)$ & $71.2(62.8)$ & $48.3(15.2)$ \\
\hline Lutjanidae & $13.1(5.0)$ & $6.5(2.0)$ & $12.4(6.6)$ & $6.6(2.7)$ \\
\hline Mullidae & $0.1(0.1)$ & $0.8(0.6)$ & $0.8(0.3)$ & $0.6(0.1)$ \\
\hline Pomacanthidae & $0.9(0.2)$ & $0.4(0.1)$ & $1.3(0.9)$ & $1.8(0.5)$ \\
\hline Chaetodontidae & $2.8(0.8)$ & $2.6(0.8)$ & $4.3(1.1)$ & $4.4(1.6)$ \\
\hline Chromis cyanea & $5.1(1.8)$ & $12.1(7.1)$ & $1.8(1.8)$ & $5.4(1.8)$ \\
\hline Stegastes sp. & $89.5(17.1)$ & $104.3(3.9)$ & $87.3(8.1)$ & $126.9(19.2)$ \\
\hline Bodianus rufus & $1.1(1.0)$ & $4.5(1.5)$ & $0.5(0.5)$ & $22.3(2.5)$ \\
\hline Halichoeres bivittatus & $2.0(1.5)$ & $1.8(0.8)$ & $0.9(0.6)$ & $1.4(0.8)$ \\
\hline Halichoeres garnoti & $12.5(3.3)$ & $15.4(3.1)$ & $17.8(5.1)$ & $22.3(2.5)$ \\
\hline Thalassoma bifasciatum & $27.8(6.4)$ & $55.4(8.4)$ & $32.6(3.8)$ & $66.8(10.0)$ \\
\hline Scarus croicensis & $50.6(6.8)$ & $44.8(4.9)$ & $30.8(4.5)$ & $38.1(10.8)$ \\
\hline Sparisoma aurofrenatum & $25.4(8.8)$ & $27.5(8.8)$ & $27.6(6.4)$ & $29.3(6.7)$ \\
\hline Sparisoma viride & $10.3(0.9)$ & $17.8(2.8)$ & $6.5(1.0)$ & $15.9(0.8)$ \\
\hline Acanthurus bahianus & $2.6(0.7)$ & $6.3(2.3)$ & $3.0(1.4)$ & $1.8(0.3)$ \\
\hline Acanthurus chirurgus & $2.5(1.1)$ & $2.5(0.8)$ & $1.6(1.0)$ & $0.9(0.6)$ \\
\hline Acanthurus coeruleus & $25.0(6.8)$ & $46.5(6.9)$ & $17.4(3.0)$ & $24.3(1.5)$ \\
\hline Species richness & $20.6(0.7)$ & $19.6(0.9)$ & $17.9(1.5)$ & $20.8(0.8)$ \\
\hline
\end{tabular}




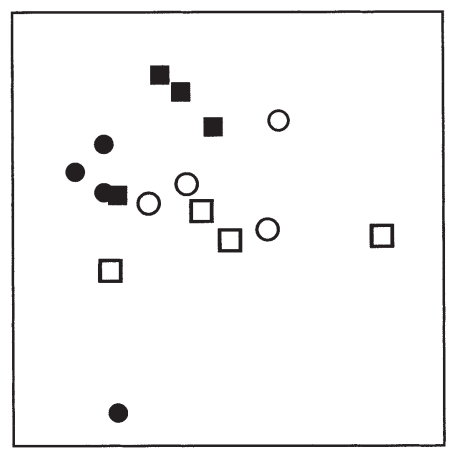

Fig. 2. Multidimensional scaling plots of biomass of 6 common surgeonfishes and parrotfishes on patch reefs in Glovers Reef lagoon. Of the fish assemblages observed, 8 were sampled on patch reefs in the wilderness zone, and 8 were sampled in the general use zone. The fish fauna was examined after macroalgae had been removed from half of the reefs in each zone. A stress value of 0.09 indicated that the 2-dimensional ordination constituted a good representation of a relationship in multidimensional space. Symbols as in Fig. 1

rus coeruleus (>18 cm) appeared influenced by management, and therefore the biomass of this surgeonfish was significantly higher in the wilderness zone than in the general use zone (ANOVA, $p=0.01^{*}$ ). Fish-species richness did not differ between manipulated and unmanipulated reefs, nor did it differ between management zones (ANOVA, p > 0.05).

Comparisons of bite and aggression rates of herbivorous fishes on shoulder/edge and the center of patch reefs pooled data for the 3 Acanthurus species as well as those for the 2 Stegastes species, as they exhibited no intra-generic difference in patterns. On reefs from which algae had been removed, the bite rate on both shoulder/edge and center sites increased significantly for Acanthurus spp. (Kruskal-Wallis test, $\mathrm{p}<0.001, \mathrm{n}=$ 320 and $n=307$ for shoulder/edge and center respectively) and Stegastes spp. ( $\mathrm{p}<0.05, \mathrm{n}=240$ and $\mathrm{p}<$ (a) Bites - reef edge

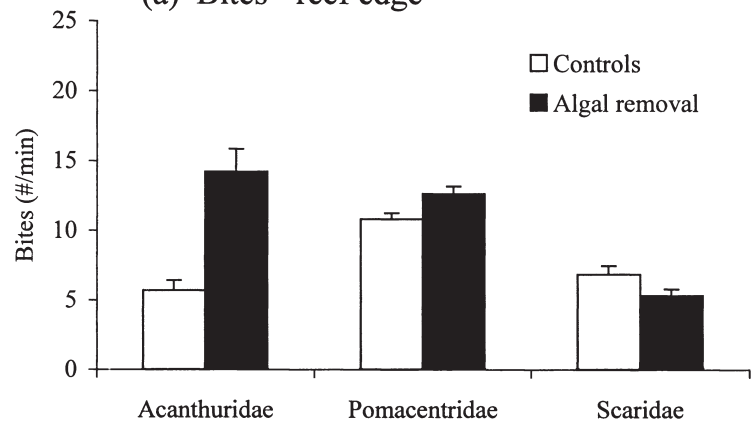

(a) Bites - reef center

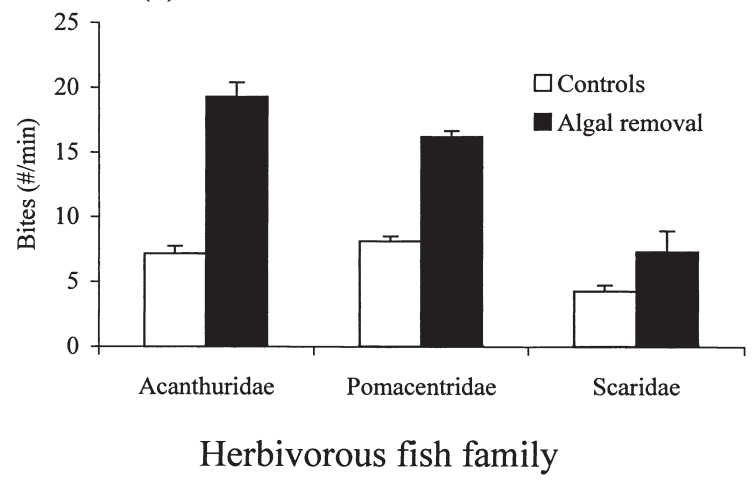

Fig. 3. Bite rates per 1 min observation in control and experimental algal reduction patch reefs for Acanthuridae, Pomacentridae (Stegastes spp.) and Scaridae in the patch reef edge (a) and patch reef center (b) positions. Bars are standard errors of the mean

0.001, n = 399 respectively; Fig. 3). Similarly, aggression rates increased for Acanthurus spp. ( $\mathrm{p}<0.05, \mathrm{p}<$ $0.001)$, Stegastes spp. $(\mathrm{p}<0.001)$, and Sparisoma viride ( $\mathrm{p}<0.05, \mathrm{n}=136$ and $\mathrm{p}<0.001, \mathrm{n}=57$ for shoulder/ edge and center respectively; Fig. 4).

Table 3. Average Scaridae and Acanthuridae biomass (g), calculated from observations of fish abundance per $5 \mathrm{~cm}$ size class per 5 min count, on control reefs $(n=8)$ and reefs subjected to algal removal $(n=8)$. Species were ranked according to their mean contribution to the Bray-Curtis dissimilarity between control and experimental reefs. $\bar{\delta}_{i}$ is the contribution of the $i$ th species to the average Bray-Curtis dissimilarity $(\bar{\delta})$, also expressed as percentage contribution $\left(\bar{\delta}_{i} \%\right)$ and cumulative percentage $\left(\sum \bar{\delta}_{i} \%\right)$. $\bar{\delta}=$ 19.57 between control and experimental reefs following the algae reduction. Ratio between the average contribution to betweengroup dissimilarity and its standard deviation $\left(\bar{\delta}_{i} / \mathrm{SD}\left[\delta_{i}\right]\right)$ is a predictor of how consistently the ith species is contributing to the overall dissimilarity

\begin{tabular}{|lrccrrr|}
\hline & Control & Removal & $\bar{\delta}_{i}$ & $\bar{\delta}_{i} / \operatorname{SD}\left(\delta_{i}\right)$ & $\bar{\delta}_{i} \%$ & $\sum \bar{\delta}_{i} \%$ \\
\hline Sparisoma viride & 1120 & 6327 & 5.56 & 2.49 & 28.42 & 28.42 \\
Acanthurus chirurgus & 392 & 331 & 3.84 & 1.47 & 19.62 & 48.04 \\
Acanthurus coeruleus & 2042 & 4900 & 3.22 & 1.35 & 16.46 & 64.50 \\
Sparisoma aurofrenatum & 804 & 2044 & 3.08 & 1.79 & 15.74 & 80.23 \\
Acanthurus bahianus & 259 & 681 & 2.65 & 1.15 & 13.54 & 93.77 \\
Scarus croicensis & 248 & 232 & 1.22 & 1.35 & & 6.23 \\
\hline
\end{tabular}




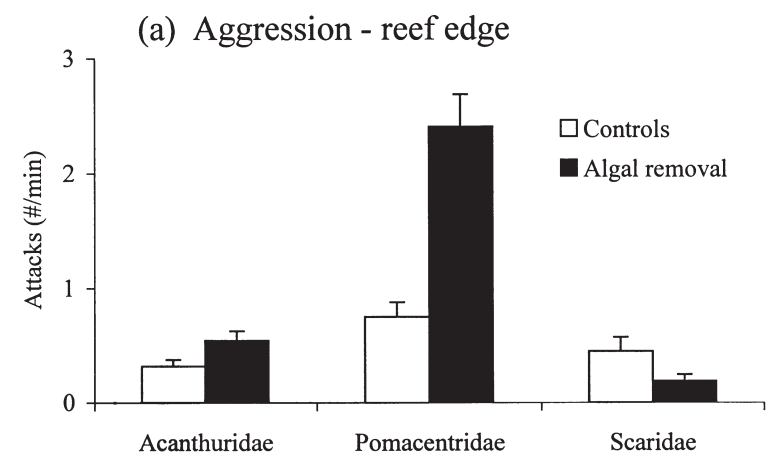

(a) Aggression - reef center

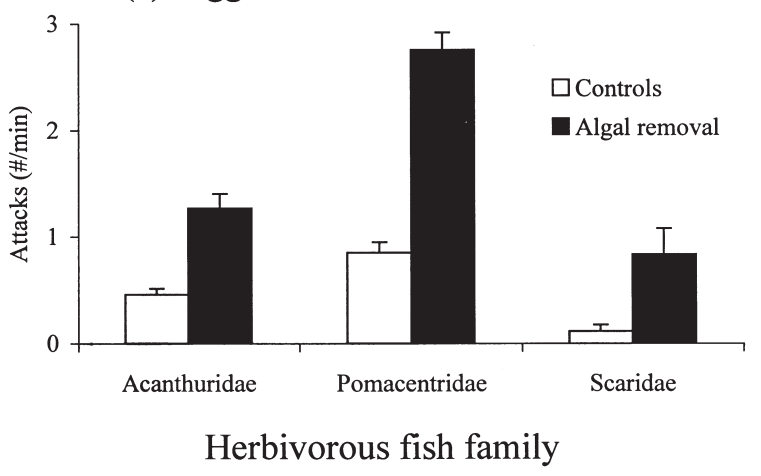

Fig. 4. Aggression rates per 1 min observation in control and experimental algal reduction patch reefs for Acanthuridae, Pomacentridae (Stegastes spp.) and Scaridae in the patch reef edge (a) and patch reef center (b) positions. Bars are standard errors of the mean

\section{DISCUSSION}

The experimental algae-reduction technique was successful in reducing macroalgae (fleshy, calcareous and branching coralline algae) and increasing relative algae turf and coral canopy cover. The manipulation was expected to change the substratum from dominance by late successional macroalgae (McClanahan 1997, McClanahan et al. 1999b) towards early successional species of turf-forming and encrusting-coralline algae, which frequently dominate heavily grazed coral reefs (Klumpp \& McKinnon 1989, 1992, Steneck 1989, McClanahan 1997). Prior to the reduction, these patch reefs were dominated by fleshy brown algae of the genera Turbinaria, Sargassum and Lobophora (McClanahan \& Muthiga 1998). Consequently, the manipulation should have increased both the net production and palatability of the algal assemblage on these reefs as well as the exposure of turf and encrusting-coralline algae (Birkeland et al. 1985). In essence, we reversed an algal succession which has been occurring in many Caribbean reefs in the last 18 yr (Carpenter 1990,
Hughes 1994, Shulman \& Robertson 1997, McClanahan \& Muthiga 1998). This succession has been associated with reduced herbivory (Hughes et al. 1999), increased nutrient concentration (LaPointe 1999) and coral death through diseases and bleaching (McClanahan et al. 1999a). Our study allowed us to determine some of the consequences of this fleshy algae proliferation on coral-reef fishes and its possible interaction with fisheries management. We also intended to compare the findings of this study with those of a similar manipulation undertaken in a 25 yr-old coral reef park in Kenya (McClanahan et al. 1999b).

The composition of the fish fauna on patch reefs in the Glovers Reef atoll appeared to be influenced by the removal of macroalgae, as illustrated by multidimensional scaling ordination. The effect was, however, only significant when applied to a limited assemblage of common herbivores, using biomass estimates instead of abundance data. Juvenile surgeonfish (Acanthuridae) and parrotfish (Scaridae) were common on the examined reefs and constituted a large part of these families' numbers. Classification of individuals according to size classes revealed that the difference in abundance between control and experimental reefs was more pronounced in adult fishes, presumably because of their increased mobility. Adult surgeonfishes and parrotfishes often move in mixed schools among patches of reef and areas of seagrass, exploring available resources (Robertson et al. 1979), and are often found in proportion to these resources (van Rooij et al. 1996b, Lawson et al. 1999). Hence, for herbivorous fishes, biomass estimates produced the most relevant description of the immediate response to algae reduction.

Species-specific responses to the reduction of algae were evident for 2 of the dominant herbivores, Sparisoma viride and Acanthurus coeruleus. The former species also contributed most to the observed dissimilarities between manipulated and unmanipulated reefs. These species would appear to be most dependent on early successional turfs, as determined by this and other studies (Bruggemann et al. 1994a,b, van Rooij et al. 1996b, Lawson et al. 1999). A population increase was also found for the invertebrate-feeding wrasse Thalassoma bifasciatum (Labridae). While the response of herbivores to the algae reduction could be related to the movement of larger fishes, the response of $T$. bifasciatum may have been due to increased activity or visibility after the reduction. This species has, however, been observed to move over large distances of as much as $1.5 \mathrm{~km}$ for the purpose of participating in mating aggregations (Warner 1995) and could, therefore, have migrated from other patch reefs. $T$. bifasciatum appeared to be actively feeding and mating (McClanahan pers. obs.) on the algae-reduc- 
tion reefs, and disturbance to the algae may have increased access to its prey.

Herbivorous surgeonfishes and damselfishes fed at faster rates and were more aggressive on experimental reefs, suggesting improved feeding conditions and, therefore, increased resource defense following the manipulation (Carpenter \& MacMillen 1976, Eakin 1987). The algal reduction study in a Kenyan park found a similar response of increased abundance and feeding rates for many herbivorous species, but notably not for macrophyte-feeding parrotfishes of the genera Leptoscarus and Calotomus (McClanahan et al. 1999b), which are genera not found in the Caribbean fauna. In our Caribbean study, bite and aggression rates were more pronounced on the reef center, which originally contained the most algae and exhibited the lowest levels of herbivory, than on the edge positions of the reef (McClanahan \& Muthiga 1998, McClanahan 1999).

Fisheries management was a weak factor in this study in relation to benthic cover and numbers of fishes. Fish assemblages did not differ in composition nor in species richness between the restricted and nonrestricted zones. In the wilderness zone, however, a few species, particularly large size classes, were more abundant or exhibited a proportionally higher increase following algae reduction. The difference was however only significant for Acanthurus coeruleus biomass, which prior to manipulation was $30 \%$ higher in the wilderness zone than in the general use zone, and almost 3 times as high in the wilderness zone following the reduction of macroalgae. Consequently, either fishing was having only a small influence on reef fishes in this remote atoll (but see McClanahan \& Muthiga 1998 and McClanahan 1999), or perhaps management is still of too recent or ineffective. Small differences were not likely to be detected by our sampling effort and an alternative sampling design and effort may be required to determine the effects of management in these early stages of closure from fishing. The Kenyan study (McClanahan et al. 1999b) was undertaken in a park that has been protected from fishing for $25 \mathrm{yr}$ (Watamu Marine National Park, WMNP), and it is notable that the response of fishes to algae reduction was greater in this older park in terms of numbers, specific diversity, and feeding habits than in the study reported here. Beyond increases in parrot and surgeonfish numbers and feeding rates in the WMNP, there were also increases in angelfish, butterflyfish, and triggerfish numbers, although it is not known whether this was a response to changes in resources or simply a multispecies schooling behavior catalyzed by herbivorous fishes.

The implication of these 2 studies is that domination of coral reefs by macroalgae (i.e. $>2 \mathrm{~kg}$ wet $\mathrm{wt} \mathrm{m}^{-2}$ or
$40 \%$ of the substrate) reduces the abundance and feeding rates of a number of herbivorous fishes, but also of invertebrate feeders. This may seem counter intuitive, as it is arguable if herbivores would respond positively to additional plant and algal resources. However, most herbivorous fishes, with the exception of a small guild of macrophyte feeders, prefer turf algae (Choat 1991), and the overgrowth of turf algae and encrusting corallines by fleshy algae appears to suppress many herbivorous fishes. Previous studies have focused on the effects of macroalgal overgrowth on corals (Hughes 1994, McClanahan et al. 1995, Tanner 1995), but our composite studies of reefs from 2 oceans suggest that the ecological degradation of reefs by macroalgal overgrowth is also suppressing some species of fishes, particularily herbivores.

Acknowledgements. This research was supported by The Wildlife Conservation Society (WCS) with financial assistance of the Pew Fellows in Conservation and the Environment Program, The Disney Foundation (T.R.M.), The Eppley Foundation (T.R.M., M.M., K.B.), the University of Stockholm, Department of Systems Ecology (I.N., T.E., M.N.), the John D. and Catherine T. MacArthur Foundation and the Marcus Wallenberg Foundation for International Scientific Co-operation through the Resilience Network at the Beijer Institute for Ecological Economics (M.H.). We would like to thank N. Kautsky and C. Folke for their assistance in organizing the BABA group. We also thank E. Ólafsson for valuable comments on the manuscript. Permission to undertake the work was provided by the Belizean Fisheries Department. We are grateful for the logistic support provided by the staff of the WCS Middle Cay Research Station; this is contribution no. 7 from this field station.

\section{LITERATURE CITED}

Aronson RB, Precht WF, Macintyre IG (1998) Extrinsic control of species replacement on a Holocene reef in Belize: the role of coral disease. Coral Reefs 17:223-230

Bellwood DR (1990) A functional analysis of grazing in parrotfishes (family Scaridae): The ecological implications. Environ Biol Fish 28:189-214

Birkeland C, Nelson SG, Wilkins S, Gates P (1985) Effects of grazing of herbivorous fishes on coral reef community metabolism. Proc 5th Int Coral Reef Symp 4:47-51 (Gabrié C, Harmelin VM [eds] Antenne Museum-EPHE, Moorea, French Polynesia)

Bohnsack JA, Harper DE (1998) Length-weight relationships of selected marine reef fishes from the Southeastern United States and the Caribbean. NOAA Natl Mar Fish Serv Tech Memor US Dep Commerce SEFC-215:1-31

Bray JR, Curtis JT (1957) An ordination of the upland forest communities of Southern Wisconsin. Ecol Monogr 27: 325-349

Bruggemann JH, Begeman J, Bosma EM, Verburg P, Breeman AM (1994a) Foraging by the stoplight parrotfish Sparisoma viride. II. Intake and assimilation of food, protein and energy. Mar Ecol Prog Ser 106:57-71

Bruggemann JH, Kuyper MWM, Breeman A (1994b) Comparative analysis of foraging and habitat use by the sympatric 
Caribbean parrotfish Scarus vetula and Sparisoma viride (Scaridae). Mar Ecol Prog Ser 112:51-66

Carpenter RC (1990) Mass mortality of Diadema antillarum. I. Long-term effects on sea urchin population-dynamics and coral reef algal communities. Mar Biol 104:67-77

Carpenter FL, MacMillen RE (1976) Threshold model of feeding territoriality and test with a Hawaiian honeycreeper. Science 194:639-642

Choat JH (1991) The biology of herbivorous fishes on coral reefs. In: Sale PF (ed) The ecology of fishes on coral reefs. Academic Press, New York, p 120-155

Clarke KR (1988) Statistical design and analysis for a 'biological effects' study. Mar Ecol Prog Ser 46:213-226

Clarke KR (1993) Non-parametric multivariate analyses of changes in community structure. Aust J Ecol 18:117-143

Cockey E, Hallock P, Lidz BH (1996) Decadal-scale changes in benthic foraminiferal assemblages off Key Largo, Florida. Coral Reefs 15:237-248

Connell JH (1997) Disturbance and recovery of coral assemblages. Coral Reefs 16:S101-S113

Done TJ (1992) Phase shifts in coral reef communities and their ecological significance. Hydrobiologia 247:121-132

Duffy JE, Hay ME (1991) Food and shelter as determinants of food choice by an herbivorous marine amphipod. Ecology 72:1286-1298

Eakin MC (1987) Damselfishes and their algal lawns: a case of plural mutualism. Symbiosis 4:275-288

Gischler E (1994) Sedimentation of three Caribbean atolls: Glovers Reef, Lighthouse Reef and Turneffe Islands, Belize. Facies 31:243-254

Glynn PW (1993) Coral reef bleaching: ecological perspectives. Coral Reefs 12:1-17

Greene LE, Alevizon WS (1989) Comparative accuracies of visual assessment methods for coral reef fishes. Bull Mar Sci 44:899-912

Holm S (1979) A simple sequentially rejective multiple test procedure. Scand J Statist 6:65-70

Hughes TP (1994) Catastrophes, phase shifts, and large-scale degradation of a Caribbean coral reef. Science 265: 1547-1551

Hughes TP, Szmant AM, Steneck R, Carpenter R, Miller S (1999) Algal blooms on coral reefs: what are the causes? Limnol Oceanogr 44:1583-1586

Klumpp DW, McKinnon AD (1989) Temporal and spatial patterns in the primary production of a coral reef epilithic algal community. J Exp Mar Biol Ecol 131:1-22

Klumpp DW, McKinnon AD (1992) Community structure, biomass and productivity of epilithic algal communities on the Great Barrier Reef: dynamics at different spatial scales. Mar Ecol Prog Ser 86:77-89

Knowlton N (1992) Thresholds and multiple stable states in coral reef community dynamics. Am Zool 32:674-682

Koslow JA, Hanley F, Wicklund R (1988) Effects of fishing on reef fish communities at Pedro Bank and Port Royal Cays, Jamaica. Mar Ecol Prog Ser 43:201-212

LaPointe BE (1999) Simultaneous top-down and bottom-up forces control macroalgal blooms on coral reefs. Limnol Oceanogr 44:1586-1592

Lawson GL, Kramer DL, Hunte W (1999) Size-related habitat use and schooling behavior in two species of surgeonfish (Acanthurus bahianus and A. coeruleus) on a fringing reef in Barbados West Indies. Environ Biol Fish 54:19-33

Lessios HA (1988) Mass mortality of Diadema antillarum in the Caribbean: what have we learned? Annu Rev Ecol Syst 19:371-393

Littler MM, Littler DS (1980) The evolution of thallus form and survival strategies in benthic marine macroalgae: field and laboratory tests of a functional form model. Am Nat 116:25-44

McClanahan TR (1994) Kenyan coral reef lagoon fish: effects of fishing, substrate complexity, and sea urchins. Coral Reefs 13:231-241

McClanahan TR (1995) A coral reef ecosystem-fisheries model: impacts of fishing intensity and catch selection on reef structure and processes. Ecol Model 80:1-19

McClanahan TR (1997) Primary succession of coral-reef algae: differing patterns on fished versus unfished reefs. J Exp Mar Biol Ecol 218:77-102

McClanahan TR (1999) Predation and the control of the sea urchin Echinometra viridis and fleshy algae in the patch reefs of Glovers Reef, Belize. Ecosystems 2:511-523

McClanahan TR, Muthiga NA (1998) An ecological shift in a remote coral atoll of Belize over 25 years. Environ Conserv 25:122-130

McClanahan TR, Shafir SH (1990) Causes and consequences of sea urchin abundance and diversity in Kenyan coral reef lagoons. Oecologia 83:362-370

McClanahan TR, Kamukuru AT, Muthiga NA, Gilagabher Yebio M, Obura D (1995) Effect of sea urchin reductions on algae coral and fish populations. Conserv Biol 10:136-154

McClanahan TR, Aronson RB, Precht WF, Muthiga NA (1999a) Fleshy algae dominate remote coral reefs of Belize. Coral Reefs 18:61-62

McClanahan TR, Hendrick V, Rodrigues MJ, Polunin NVC (1999b) Varying reponses of herbivorous and invertebrate-feeding fishes to macroalgal reduction on a coral reef. Coral Reefs 18:195-203

Mumby PJ (1999) Bleaching and hurricane disturbances to populations of coral recruits in Belize. Mar Ecol Prog Ser 190:27-35

Polunin NVC, Harmelin-Vivien M, Galzin R (1995) Contrasts in algal food processing among five herbivorous coral-reef fishes. J Fish Biol 47:455-465

Porter JW, Meier OW (1992) Quantification of loss and change in Floridian reef coral populations. Am Zool 32:625-640

Robertson DR, Polunin NVC, Leighton K (1979) The behavioral ecology of three Indian Ocean surgeonfishes (Acanthurus lineatus, A. leucosternum, and Zebrasoma scopas): their feeding strategies, and social and mating systems. Environ Biol Fish 4:125-170

Rogers CS (1993) Hurricanes and coral reefs: the intermediate disturbance hypothesis revisited. Coral Reefs 12:127-137

Shulman MJ, Robertson DR (1997) Changes in the coral reef of San Blas, Caribbean Panama: 1983 to 1990. Coral Reefs 15:231-236

Stachowicz JJ, Hay ME (1996) Facultative mutualism between an herbivorous crab and a coralline alga: advantages of eating noxious seaweeds. Oecologia 105:377-387

Steneck RS (1989) Herbivory on coral reefs: a synthesis. Proc 6th Int Coral Reef Symp 1:37-49 (Choat JH et al. [eds] Sixth International Coral Reef Symposium Executive Committee, Townsville)

Steneck RS, Dethier MN (1994) A functional group approach to the structure of algal-dominated communities. Oikos 69:476-498

Stoddart DR (1962) Three Caribbean atolls; Turneffe Islands, Lighthouse Reef and Glovers Reef British Honduras. Atoll Res Bull 87:83-122

Tanner JE (1995) Competition between scleractinian corals and macroalgae: an experimental investigation of coral growth, survival and reproduction. J Exp Mar Biol Ecol 190:151-168

Van Rooij JM, de Jong E, Vaandrager F, Videler JJ (1996a) Resource and habitat sharing by the stoplight parrotfish 
Sparisoma virde a Caribbean reef herbivore. Environ Biol Fish 47:81-91

Van Rooij JM, Kok JP, Videler JJ (1996b) Local variability in population structure and density of the protogynous reef herbivore Sparisoma viride. Environ Biol Fish 47:65-80

Wahl M, Hay ME (1995) Associational resistance and shared doom: effects of epibiosis on herbivory. Oecologia 102: $329-340$

Wallace RJ, Shafersmann SD (1977) Patch reef ecology and sedimentology of Glovers Reef Atoll, Belize. In: Frost SH, Weiss MP, Saunders JB (eds) Reefs and related carbonates: ecology and sedimentology. American Association of Petroleum Geologists, Tulsa, OK, p 37-53

Warner RR (1995) Large mating aggregations and daily longdistance spawning migrations in the bluehead wrasse

Editorial responsibility: Otto Kinne (Editor),

Oldendorf/Luhe, Germany
Thalassoma bifasciatum. Environ Biol Fish 44:337-345B

Warwick RM, Clarke KR, Suharsono (1990) A statistical analysis of coral community responses to the 1982-1983 El Niño in the thousand Islands, Indonesia. Coral Reefs 8:171-179

Winter A, Appeldoorn RS, Bruckner A, Williams JREH, Goenaga C (1998) Sea surface temperatures and coral reef bleaching off La Parguera, Puerto Rico (northeastern Caribbean Sea). Coral Reefs 17:377-382

Woodley DJ, Chornesky EA, Clifford PA, Jackson JBC, Kaufman LS, Knowlton N, Land JC, Pearson MP, Porter JW, Rooney MC, Rylaarsdam KW, Tunnicliffe VJ, Wahle CM, Wulff JL, Curtis ASG, Dallmeyer MD, Jupp BP, Koehl MAR, Niegel J, Sides EM (1981) Hurricane Allen's impact on Jamaican coral reefs. Science 214:749-755

Submitted: November 3, 1999; Accepted: June 22, 2000 Proofs received from author(s): October 9, 2000 